\title{
Extent of Adoption of Farmers about Bt Cotton Practices in Warangal District of Telangana State, India
}

\author{
P. Pavan Kumar* and R.K. Dhorey \\ Department of Agricultural Extension, Narendra Dev University of Agriculture and Technology \\ Faizabad-224229 (U.P.), India \\ *Corresponding author
}

\section{A B S T R A C T}

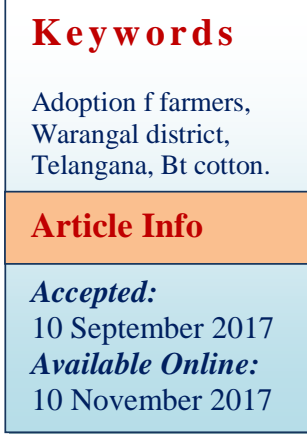

\section{Introduction}

Cotton (Gossypium hirsutum L.) referred to as the White Gold is one of the most important fiber and commercial crop playing a key role in economic, political and social affairs in our country as well as world. Cotton occupies a predominant place among cash crops touching the country's economy at several points by generating direct and indirect employment in the agricultural and industrial sectors. Following a long history of cultivation of traditional varieties, hybrid cotton was introduced in India for the first time in 1970.This was in the state of Gujarat and by virtue of its high yield potential it became very popular. However it was soon realized that the hybrids were highly susceptible to pest attack and damage. This became a severe problem especially from 1993-94 onwards, leading to frequent crop failures as well as fluctuating declining yields. Over 150 different insect pests species are reported to attack cotton at various stages of its growth causing sever reduction in yields, and reduction in massive pesticide use by farmers and high cost of cultivation. It is estimated that over $55 \%$ of the pesticides sold in the Country are used on cotton. It was at this juncture that the transgenic varieties with $\mathrm{Bt}$. arrived on the world and then in the country. Bt. cotton, the first genetically modified (GM) crop in India, was initially approved in India on March 26th 2002 for commercial 
cultivation in six states belonging to southern and central cotton cultivation zones of the country. The commercial cultivation of Bt. cotton in the world first began in 1996. The reason for the introduction of $\mathrm{Bt}$ cotton was to counter attack the three types of bollworms, viz. American bollworm (Helicoverpa armigera), pink bollworm (Pectinophora gossypiella) and spotted bollworms (Earias vitella) which used to cause substantial damage to the crop, resulting in low productivity. Therefore, Mahyco (Maharashtra Hybrid Seed Company), in collaboration with Monsanto, introduced Bt. cotton technology into India. Bt. Cotton carries the CrylAc gene derived from the common soil bacterium Bacillus thuringiensis var. kurstaki, which results in the expression of the Cry1Ac protein that confers resistance to the bollworm complex (Barwal et al., 2004). Bt. cotton hybrids have exhibited excellent control of American Bollworm and reduced the use of insecticides. This has led to create eco-friendly environment without compromising on profitable yield (Manikin et $a l .$, 2008). In addition to reducing production cost and increasing profit, Bt. cotton has lowered farming risk and improved farmer's perspective in cultivating cotton crop.

\section{Materials and Methods}

Warangal district of Telangana will be purposively selected for higher production of Bt. cotton, Warangal is the second largest Bt. Cotton producer in Telangana state with the area of more than 2 lakh hectares of land, and locale for present investigation because the researcher is well acquainted with the locality and culture. District Warangal comprised of 9 Community development blocks. Out of these 9 blocks, the Warangal block will be selected purposively for the study because of the Warangal block is second largest producer of Bt. Cotton in district and its easy accessibility and familiarity of researcher with the local language, socio economic and cultural conditions. An exhaustive list of village of Warangal block will be prepared and 5 villages will be selected randomly. Moreover, list of farm families from each of the selected village will be prepared and 20 respondents from each of the selected village will be identified through random sampling technique. Thus a total of 100 rural farmers constitute the sample size for the purpose of further investigation. A knowledge test was developed. Data was collected using interview schedule developed for the study. Based on obtained scores the respondents were grouped into low, medium and high knowledge categories according to equal interval method. The collected data was analyzed using appropriate statistical tools like frequency and percentage, class interval, arithmetic mean $(X)$, standard deviation and co- efficient of correlation.

The overall adoption maximum and minimum possible scores was 0 to 30 . By summing up individual scores the maximum and minimum obtained score was 16 to 21. Based on obtained scores the respondents were grouped into low, medium and high knowledge categories according to equal interval method as shown below.

\section{Results and Discussion}

From Table 2 it was evident that, majority of the farmers $(70 \%)$ had medium level of adoption followed by low (18.00\%), high $(12 \%)$ level of adoption.

The reason for this kind of result might be due to their medium to low levels of knowledge, medium education, medium risk orientation, medium extension contacts, medium farm mechanization status, medium Social participation, medium risk orientation and medium scientific orientation. 
Overall extent of adoption of farmers Vs profile characteristics

\section{Null hypothesis}

There will be no significant relationship between the extent of adoption of Bt. Cotton practices by the respondents and their profile characteristics and both of these are independent.

\section{Empirical hypothesis}

There will be significant relationship between the extent of adoption of Bt. Cotton practices by the respondents and their profile characteristics and both of these are dependent.

It is revealed from the table 3 that calculated ' $r$ ' values between scientific orientation and the extent of adoption of Bt. Cotton practices by the respondents were greater than table $\mathrm{V}$ value at 0.05 level of probability, whereas, the calculated ' $r$ ' value of the variables age, education, caste, size of land holding, annual income, material possession, economic motivation, extension contact were greater than table ' $r$ ' value at 0.01 level of probability. Hence, null hypothesis was rejected and empirical hypothesis was accepted for these variables.

On the other hand the calculated ' $r$ ' values between knowledge type of family, size of family, occupation, social participation, risk orientation were less than table ' $r$ ' value. Hence null hypothesis accepted and empirical hypothesis was rejected. Therefore, it can be concluded that there was no significant relationship between above characteristic and knowledge of famers.

Probable reason for these results might be that their medium to low levels of knowledge, medium education, medium extension contacts, medium farm mechanization status, medium risk orientation, medium extension contacts, medium farm mechanization status, medium Social participation, medium risk orientation and medium scientific orientation would enable a farmer to get acquainted with up to date knowledge and increased knowledge levels lead to adoption when a farmer is more innovative, willing to take risk and has access to farm mechanization.

\section{Relationship between profile characteristics with extent of adoption of respondents}

\section{Age Vs Extent of adoption}

The table 3 highlights that, the variable age was in negatively significant associated with extent of adoption of farmers, the reason might be that majority of the respondents were middle aged. This age farmers are less innovative as compared to young age.

\section{Education Vs Extent of adoption}

The results inferred from the table 3 revealed that there was a positive and significant association between education and extent of adoption of respondents. Education enhances the level of adoption of respondents. Higher the education, wider and better will be the interaction. It is a well-known fact that education brings desirable changes by in knowledge, adoption and social status. The higher the education of a person, the more extent of adoption and vice versa. Hence this kind of relationship appeared in the investigation.

\section{Caste Vs Extent of adoption}

The results inferred from the table 3 revealed that there was a positive and significant association between caste and extent of adoption of respondents 
Table.1 Scoring and categorisation

\begin{tabular}{|l|l|l|}
\hline S. No. & Category & Score \\
\hline 1. & low & $0-16$ \\
\hline 2. & Medium & $17-20$ \\
\hline 3. & High & 21 and above \\
\hline
\end{tabular}

Table.2 Distribution of the respondents based on their overall extent of adoption of Bt. cotton practices

$(\mathrm{N}=100)$

\begin{tabular}{|l|l|c|c|}
\hline S.No & \multirow{2}{*}{$\begin{array}{l}\text { Categories } \\
\text { (score value) }\end{array}$} & \multicolumn{2}{|c|}{ Categories (score value) } \\
\cline { 3 - 4 } & Low & 18 & Pumber \\
\hline 1 & Medium & 70 & 70 \\
\hline 2 & High & 12 & 12 \\
\hline 3 & & \multicolumn{2}{c}{} \\
\hline
\end{tabular}

Table.3 Relationship between profile characteristics and extent of adoption of Bt. cotton practices

\begin{tabular}{|c|c|c|}
\hline S. No. & Independent Variable & Correlation Coefficient \\
\hline 1 & Age & $-0.26642^{* *}$ \\
\hline 2 & Education & $0.391059^{* *}$ \\
\hline 3 & Caste & $0.484741^{* *}$ \\
\hline 4 & Type of family & 0.183076 \\
\hline 5 & Size of family & 0.099904 \\
\hline 6 & Size of land holding & $0.528163^{* *}$ \\
\hline 7 & Occupation & 0.02505 \\
\hline 8 & Annual income & $0.374769^{* *}$ \\
\hline 9 & Social participation & 0.048375 \\
\hline 10 & Material possession & $0.46628^{* *}$ \\
\hline 11 & Economic motivation & $0.36627^{* *}$ \\
\hline 12 & Extension contact & $0.431299^{* *}$ \\
\hline 13 & Risk orientation & 0.054122 \\
\hline 14 & Scientific orientation & $0.215556^{*}$ \\
\hline
\end{tabular}

*Significant at $0.05 \%$ probability level**

Significant at $0.01 \%$ probability level. $(\mathrm{N}=100)$

\section{Type of family Vs Extent of adoption}

The variable type of family had positive and non-significant relationship with extent of adoption of farmers, the reason might be that majority of the respondents were nuclear/single family.

\section{Size of family Vs Extent of adoption}

The variable type of family had positive and non-significant relationship with extent of adoption of farmers, the reason might be that majority of the respondents were medium size of family. 


\section{Size of land holding Vs Extent of adoption}

The results inferred revealed that there was a positive and significant association between Size of land holding and extent of adoption of respondents. Farm size enhances the extent of adoption of respondents. Higher the farm size, more efforts are needed in crop management. It is a well-known fact that high farm size respondents grow more crops and more interested on latest technologies. Hence this kind of relationship appeared in the investigation.

\section{Occupation Vs Extent of adoption}

The variable occupation had positive and nonsignificant relationship with extent of adoption of farmers, the reason might be that majority of the respondents were observed their main occupation as agriculture.

\section{Annual income Vs Extent of adoption}

The results indicate that there was a positive and significant association between annual income and extent of adoption of respondents. The reason might be that the respondents who had more annual income they had good farm machinery, quality of seed, and they apply fertilizers and pesticides in appropriate time

\section{Social participation Vs Extent of adoption}

The variable social participation was found to have positively and non-significant association with extent of adoption of farmers, the reason might be that most of the farmers having less educational qualifications.

\section{Material possession Vs Extent of adoption}

Perusal of the table 3 indicated that there was a positive and significant association between extent of adoption and material possession of the respondents. The reason might be that the farmers who follow modern ways crop production will try to use mechanized practices. With adequate farm machinery available either with them or on rent would leads to moderate extent of adoption effectively.

\section{Economic motivation Vs Extent of adoption}

Perusal of the table 3 indicated that there was a positive and significant association between extent of adoption and economic motivation of the respondents. The reason might be that the farmer who is more economic motivation will try to gather the information on Bt. Cotton practices and adopts more quickly than rest of the farmers.

\section{Extension contact Vs Extent of adoption}

The results revealed that there was a positive and significant association between extension contact and extent of adoption of respondents. Due to frequent extension contacts there will be definitely knowledge transfer from extension agent to farmer. Logically, a farmer with more extension contacts will have more adoption of agricultural innovations. Hence this kind result was noticed.

\section{Risk orientation Vs Extent of adoption}

Perusal of the table 3 indicated that there was a positive and non- significant association between extent of adoption and risk orientation of the respondents. The reason might be that the farmer were not taking the more risk for adoption of Bt. Cotton practices due to their less educational qualifications and less income level.

\section{Scientific orientation Extent of adoption}

The results revealed that there was a positive and significant association between scientific orientation and extent of adoption of respondents. The reason might be that respondents who had more scientific orientation will have more extent of adoption of Bt. Cotton practices.

Above results concluded that majority of the farmers had medium level of adoption about Bt. Cotton Practices. 
The reason might be due to fact that their medium to low levels of knowledge, medium education, medium extension contacts, medium farm mechanization status, medium Social participation, medium risk orientation and medium scientific orientation.

So Department of Agriculture and private agencies providing training facilities to farmers regarding $\mathrm{Bt}$. Cotton practices.

\section{References}

Balakrishnan, T. and Vasanthkumar, J. (2010). Knowledge level of System of Rice Intensification (SRI) technology among farmers in Cuddalore district of Tamil Nadu. International J. of Current Research. 9: 065-068.

Desale, M.M., Badhe, D.K. and Patel, R.C. (2012). Adoption of recommended hybrid castor production technology by the castor growers. Agricultural Science Digest. 32(3): 233-236.

Jeewan, R.S., Sangram, S., Hanuman, L. and Choudhary, L.R. (2011). Knowledge level of farmers about improved tomato production technology. Rajasthan J. of Ext. Edu. 19: 139-143.

Joshi, P. L. (2004). Extent of knowledge and adoption of cotton growers about modern practices of cotton in Bhal area. M.Sc. (Ag). GAU, Anand Campus, Anand.

Kothari, G.L., Intodia, S.L. and Sharma, F.L. (2010). Knowledge and adoption of maize production technology by the farmers. Rajasthan J. of Ext. Edu.17\&18: 48-51.
Maraddi, G. N. V. and Sathish, H. S. (2014). Analysis of farmer's knowledge and adoption of improved cotton cultivation practices. Agriculture Update;9(1): 1-6.

Narula, A.M., Shashikumar, S. and Chougala, D.G. (2009). Impact of Cotton IPM Demonstration. Indian J. Ext. Edu.45:8184

Ranawat, Y., Hanuman, Sisodia, S.S. and Punjabi, N.K. (2011).Adoption of improved maize cultivation practices by trained and untrained farmers of KVK, Udaipur. Rajasthan. J. of Ext.Edu.19: 144-147.

Reddy, P. S., Srinath, B., Kishore, Naidu, B. and Raju, C. S. (2012). Knowledge and adoption levels on organic farming in mulberry cultivation with the farmers in Chittoor district of Andhra Pradesh. Crop research (Hisar); 43(112/3):284-288.

Saxena,K. K. and Singh, R. L. (2000). Adoption of organic farming practices by farmers of Malwa region. Maharashtra J. of Ext.Edu.19: 53-56

Shivalingaiah, Y. N., and Nagabhushanam, K. (2010). Adoption of improved technologies of field and vegetable crops in Southern dry zone of Karnataka. The Mysore J. of Agricultural Sciences. 44(3): 566-570.

Umesh, R. (2009). Factors influencing adoption of cotton cultivation practices in the rehabilitated areas. Mysore J. of Agricultural Sciences.43: 757-762.

Verma, P. D. and Munshi, M. A. (2000). A study on adoption of kharif groundnut production technology. Gujarat J. of Ext. Edu.10\&11: 37-40.

\section{How to cite this article:}

Pavan Kumar, P. and Dhorey, R.K. 2017. Extent of Adoption of Farmers about Bt Cotton Practices in Warangal District of Telangana State, India. Int.J.Curr.Microbiol.App.Sci. 6(11): 824-829. doi: https://doi.org/10.20546/ijcmas.2017.611.097 